\title{
Penerapan Siklus Belajar 5E Dengan Media PowerPoint Untuk Meningkatkan Aktivitas Belajar dan Hasil Belajar Siswa
}

\author{
Kaesta Uri Winggi \\ Program Studi Pendidikan IPA, STKIP PGRI Nganjuk \\ Email: kaestapuri@gmail.com
}

\begin{tabular}{|c|c|}
\hline \multicolumn{2}{|c|}{ Informasi Artikel } \\
\hline Diterima & $: 08-12-2021$ \\
\hline Revisi & $19-12-2021$ \\
\hline Diterbitkan & $20-01-2022$ \\
\hline & Keywords: \\
\hline Lear & ing Cycle $5 E$ \\
\hline & ent Activities \\
\hline & $\begin{array}{l}\text { ning s Result } \\
\text { PowerPoint }\end{array}$ \\
\hline
\end{tabular}

Abstrak

Tujuan penelitian ini adalah untuk meningkatkan aktivitas dan hasil belajar siswa menggunakan model Siklus Belajar 5E dengan media PowerPoint serta penggunaan WhatsApp Group untuk diskusi dan Google Classroom untuk penugasan pada kelas X-TKJ-2. Penelitian ini merupakan Penelitin Tindakan Kelas (PTK) dengan menggunakan pendekatan mixed method dengan analisis kuantitatif dan kualitatif. Model penelitian tindakan yang digunakan adalah model oleh Kemmis dan Mc. Taggart, dimana memiliki 4 kegiatan dalam setiap siklusnya yaitu perencanaan, tindakan, pengamatan, dan refleksi. Penelitian ini dilaksanakan di SMK Negeri 1 Nganjuk. Subjek penelitian adalah siswa kelas X-TKJ-2 sebanyak 36 orang. Objek penelitian adalah aktivitas siswa dan hasil belajar siswa. Teknik pengumpulan data dilakukan dengan teknik tes dan non tes. Teknik tes dilakukan dengan memberikan tugas pada akhir siklus. Sedangkan non tes meliputi observasi atau pengamatan kegiatan yang dilakukan siswa saat pembelajaran daring. Analisis data disajikan dalam bentuk bentuk tabel dan grafik, dengan analisi data kuantitatif yang berbentuk kata-kata atau simbol dan dilakukan analisis data kuantitatif yang berbentuk angka. Dengan menggunakan observasi terhadap hasil aktivitas belajar siswa pada pra siklus diperoleh skor 33\%, siklus I naik 10\% diperoleh skor 43\%, pada Siklus II naik 37\% diperoleh skor 80\%, telah melebihi kriteria minimal yaitu sebesar 75\%, dan memiliki kriteria tinggi. Untuk hasil belajar siswa pada pra siklus prosentase ketuntasan hasil belajar siswa adalah 28\%, kemudian pada Siklus I sebesar 36\%, Siklus II meningkat hingga 83\% siswa yang memiliki nilai diatas KKM. Kesimpulannya adalah media 
PowerPoint dengan model pembelajaran Siklus Belajar 5E dapat meningkatkan aktivitas belajar siswa dan hasil belajar siswa.

Kata Kunci : Siklus Belajar 5E, Aktivitas Siswa, Hasil Belajar, PowerPoint

\section{PENDAHULUAN}

Pandemi covid-19 masih berlangsung di seluruh dunia hingga saat ini,khususnya di Indonesia kasus masih terus meningkat. Sejak awal tahun 2020 tepatnya dibulan Maret ,untuk mencegah penularan virus covid-19 pemerintah melakukan pembatasasan sosial. Pembatasan ini juga dilakukan di sektor pendidikan, yaitu dengan dilakukannya pembelajaran dari rumah atau pembelajaran jarak jauh. Pembelajaran jarak jauh ini memanfaatkan kemajuan teknologi yang ada yaitu dengan memanfaatkan media sosial dan gawai, pembelajaran tersebut yaitu pembelajaran daring. Pembelajaran daring merupakan metode pembelajaran yang menggunakan teknologi dan jaringan internet yaitu dengan menggunakan Whatsapp, Zoom, Google Classroom atau aplikasi lainnya (Kristina, 2020). Pada tahun 2021 pembelajaran sudah dilakukan secara daring dan luring, yaitu dengan masuk ke sekolah dengan adanya pembatasan siswa atau di beberapa hari saja.

Berdasarkan observasi yang dilakukan di kelas X-TKJ 2 SMK Negeri 1 Nganjuk didapatkan hasil bahwa dilakukan pembelajaran Blended Learning. Menurut Abdullah (2018) Blended Learning adalah sebuah model pembelajaran yang menggabungkan antara pembelajaran tatap muka dengan $e$ learning (online). Penggabungan yang dilakukan secara baik antara pembelajaran tatap muka dimana guru dan siswa bertemu langsung dan melalui media online yang bisa diakses kapan saja. Blended Learning dapat menjadi metode yang baik dalam menunjang pembelajaran Kimia (Inayah, 2019). Pembelajaran Kimia di SMK Negeri 1 Nganjuk dilakukan secara luring dan daring, meliputi masingmasing kelas 50\% siswa luring dan 50\% lainnya daring. Pembatasan setengah siswa setiap kelas yang masuk dikarenkan untuk membatasi jumlah siswa yang ada di sekolah dikarenkaan pada saat itu di Kabupaten Nganjuk masih diberlakukan pembatasan. Dari hasil pengamatan di kelas X-TKJ-2 pada saat guru melakukan pembelajaran Kimia tatap muka (luring) di kelas diguanakan metode ceramah dan tanya jawab. Guru akan menjelaskan materi secara lisan dan dijelaskan di papan tulis serta melakukan tanya jawab dengan siswa untuk menjawab soal yang telah diberikan.

Pada pembelajaran Kimia yang dilakukan secara daring ,guru membuat WhatsApp Group dengan siswa untuk memberikan informasi mengenai tugas dan daftar hadir. Dalam pembelajaran daring guru hanya memberikan materi dan tugas pada siswa di Google Classroom, tidak ada diskusi pada WhatsApp Group dan siswa juga tidak bertanya tentang materi apabila kurang jelas. Siswa akan mendapatkan penjelasan tambahaan apabila melaksanakan pemeblajaran tatap muka, namun pembelajaran tatap muka dilakukan terbatas terkadang hanya satu atau dua kali saja untuk mata pelajaran kimia dalam 1 bulan ditambah lagi apabila sekolah memilki banyak kegiatan yang mengharuskan pembelajaran dilakukan secara daring. Dari uraian terebut menyebabkan siswa kurang memahami materi pelajaran sehingga hal ini berpengaruh pada hasil belajar siswa. Dari hasil observasi pembelajaran daring yang dilakukan sebanyak 26 siswa atausekitar $72 \%$ siswa yang memiliki nilai dibawah KKM (Kriteria Ketuntasan Minimal) yang ada di sekolah tersebut yaitu 70. Untuk itu diperlukan solusi untuk meingkatkan aktivitas siswa dan hasil belajarsiswa dalam pembelajaran Kimia yang dilakukan secara daring. Peningkatkan aktivitas belajar perlu ditingkatkan untuk meningkatkan pemahaman siswa dala mempelajari materi belajardan juga meningkatkan keaktifan serta kedisiplinan siswa dalam belajar. Hasil belajar siswa yang berada diatas KKM menjadi tolak ukur keberhasilan suatu pembelajarn dan juga mejadi salah satu indikator tercapainya suatu pembelajaran yaitu dari ranah kogntif. Dalam mengatasi masalah tersebut dapat digunakan perbaikan media belajar dan juga memilih model pembeajaran yang tepat.

Media pembelajaran yang dapat digunakan adalah Powerpoint. Muthaharoh (2019) mengatakan bahwa media PowerPoint merupakan salah satu program aplikasi pada Microsoft Office yang berguna untuk membuat presentasi dalam bentuk halaman. Aplikasi PowerPoint paling sering digunakan oleh guru dalam proses pembelajaran, hal ini dikarenakan penggunaan PowerPoint membuat pembelajaran menjadi mudah dan menarik karena didukung dengan pilihan-pilihan dan beberapa tema untuk memperindah tampilan presentasi. Pada saat pembelajaran daring guru dapat memberikan materi dalam bentuk PowerPoint kepada siswa ,dalam PowerPoint dapat dibuat penjelan materi dengan fitur-fitur yang ada dan menarik sehingga dapat menarik siswa semangat dan dalam mengikuti pembelajaran dan paham materi yang diajarkan untuk meningkatkan aktivitas siswa dan juga hasil belajar siswa. Adapun model pembelajaran yang dipilih untuk meningatkan aktivitas siswa dan hasil belajar siswa yaitu model pembelajaran siklus belajar tipe 5E (Learning Cycle 5E). Limbong (2019) menuliskan bahwa model pembelajaran siklus belajar tipe 5E merupakan pembelajaran berpusat pada siswa (student centered) dan 
guru sebagai fasilitator. Model pembelajaran siklus belajar ini merupakan proses kognitif yang aktif, model pembelajaran siklus belajar juga dapat membantu siswa untuk meningkatkan aktivitas siswa serta meningkatkan hasil belajar siswa. Model siklus belajar 5E dipilih karena pembelajaran berpusat pada siswa dan merupakan proses kognitif yang aktif.

Dilakukan Penelitan Tindakan Kelas (PTK) untuk meningkatkan aktivitas belajar dan hasil belajar siswa dengan menggunakan media PowerPoint dan model pembelajaran Siklus Belajar 5E (Learning Cycle 5E). Terdapat 3 indikator yang dapat menjadi acuan untuk tolak ukur kebehasilan meningkatkan aktivitas siswa yaitu aktivitas bertanya, aktivitas menjawab pertanyaan diskusi, dan aktivitas mengerjakan tugas. Dengan target pencapaian aktivitas belajar memiliki prosentase rata-rata dari ketiga indikator tersebut adalah $75 \%$ dan memiliki kriteria tinggi menurut pedoman keriteria aktivitas belajar siswa, maka dikatakan aktivitas belajar meingkat.Untuk peningkatan hasil belajar siswa tolak ukur keberhasilan dilihat dari nilai tugas siswa, dimana nilai harus diatas KKM (Kriteria Ketuntasan Minimal) yang sudah ditentukan oleh sekolah yaitu 70, dan juga prosentase ketuntasan hasil belajar memperoleh $75 \%$, dimana 27 siswa memiliki nilai diatas KKM, maka hasil belajar siswa dikatakan meningkat.

\section{METODE PENELITIAN}

Penelitian ini merupakan Penelitin Tindakan Kelas (PTK) dengan menggunakan pendekatan mixed method dengan analisis kuantitatif dan kualitatif. Model penelitian tindakan yang digunakan adalah model oleh Kemmis dan Mc. Taggart, dimana memiliki 4 kegiatan dalam setiap siklusnya yaitu planning (rencana), action (tindakan), observation (pengamatan), dan reflection (refleksi). Penelitian ini dilaksanakan di SMK Negeri 1 Nganjuk. Subjek penelitian adalah siswa kelas X-TKJ-2 sebanyak 36 orang. Objek penelitian adalah aktivitas siswa dan hasil belajar siswa. Penelitian dilaksanakam pada semester 1 Tahun Ajaran 2021/2022 pada pembelajaran kimia materi “Tata Nama Senyawa Biner". Teknik pengumpulan data dilakukan dengan teknik tes dan non tes. Teknik tes dilakukan dengan memberikan tugas pada akhir siklus. Sedangkan non tes meliputi observasi atau pengamatan kegiatan yang dilakukan siswa saat pembelajaran daring. Analisis data disajikan dalam bentuk bentuk tabel dan grafik, dengan analisi data kuantitatif yang berbentuk kata-kata atau simbol dan dilakukan analisis data kuantitatif yang berbentuk angka. Teknik analisis deskriptif dengan menggunakan presentase yaitu dilakukan dengan membandingkan aktivitas dan hasil belajar siswa antara Pra Siklus, Siklus I dan Siklus II. Penelitian Tindakan kelas dengan menggunakan siklus ini akan terus dilakukan apabila masih belum tercapai target yang ditentukan atau masalah belum terpecahkan dan apabila target sudah tercapai dan masalah sudah dapat teratari yaitu dengan meningkatnya aktivitas belajar dan hasilbelajarsiswa maka siklus berhenti. Berikut adalah alur penelitian tindakan kelas dengan model Kemmis dan Mc. Taggart :

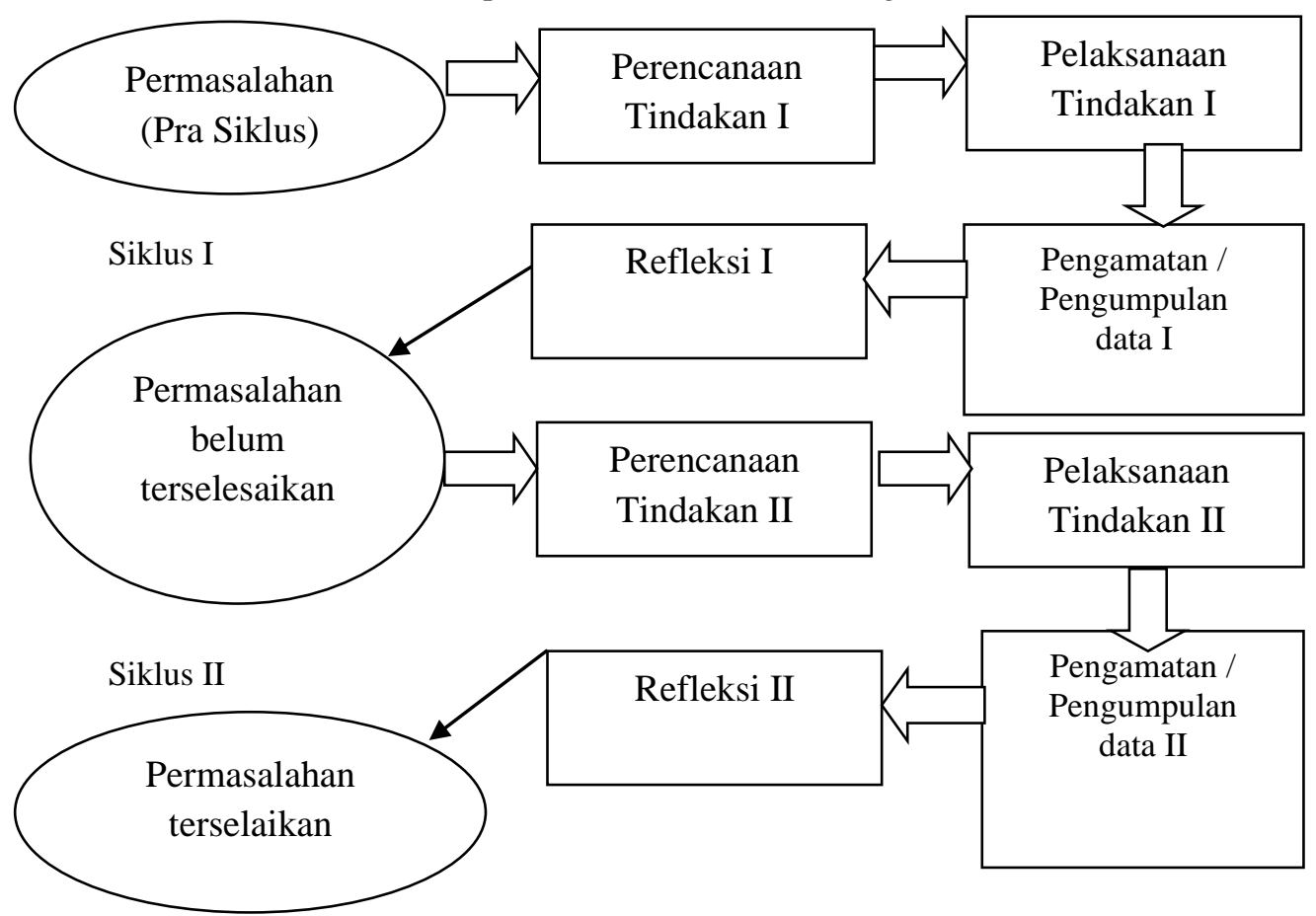

Gambar 1. Alur PTK oleh model Kemmis dan Mc. Taggart 


\section{HASIL DAN PEMBAHASAN}

Penggunaan media PowerPoint dalam pembelajaran digunakan untuk memudahkan siswa dalam menguasai konsep materi. Apabila siswa dapat menguasai konsep materi dengan baik. Penggunaan media ini juga dibarengi oleh Siklus Belajar 5E yang merupakan pembelajaran berupa rangkaian tahap-tahap kegiatan atau fase yang diorganisasi sedemikian rupa sehingga siswa dapat menguasai kompetensi yang harus dicapai dan berperan aktif. Model pembelajaran Siklus Belajar 5E dengan media PowerPoint akan memberikan kesempatan kepada siswa untuk mengoptimalkan cara belajar dan mengembangkan daya nalar siswa. Sehingga dapat meningkatkan aktivitas siswa dan hasil belajar siswa.

Pada siklus I dilakukan perencanaan yang dibuat berdasarkan permasalahan yang ditemui di kelas pada saat pra siklus, lalu akan dicari pemecahan masalahnya. Tindakan perbaikan pada siklus I yang akan dilakukan untuk mengatasi masalah tersebut melalui pembelajaran menggunakan model Siklus belajar 5E dengan media PowerPoint menggunakan aplikasi Google Classroom dan WhatsApp Group yang dilaksanakan melalui lima tahapan yaitu Tahap Pembangkitan Minat (Engigemant), Tahap Eksplorasi (Eksploration), Tahap Penjelasan (Explaination), Tahap Elaborasi (Elaboration), Tahap Evaluasi. Pada pembelajaran Kimia dengan materi "Tata Nama Senyawa Biner" dilakukan diskusi melalui WhatsApp Group. Hasil pengolahan aktivitas belajar siklus I secara rinci disajikan dalam tabel sebagai berikut :

Tabel 1. Skor Aktivitas Belajar Berdasarkan Observasi Siklus I

\begin{tabular}{|l|l|c|}
\hline No. & \multicolumn{1}{|c|}{ Indikator } & Skor \\
\hline 1. & Aktivitas Bertanya & $40 \%$ \\
\hline 2. & Aktivitas menjawab pertanyaan & $40 \%$ \\
\hline 3. & Aktivitas mengerjakan tugas & $50 \%$ \\
\hline \multicolumn{2}{|r|}{ Skor Rata-rata } & $\mathbf{4 3 \%}$ \\
\hline
\end{tabular}

Menurut Arikunto (2009) pada Mandasari (2021) merupakan pedoman kriteria aktivitas siswa pada pembelajaran sebagai berikut:

Tabel 2. Pedoman Kriteria Aktivitas Siswa

\begin{tabular}{|c|c|}
\hline Capaian & Kriteria \\
\hline $75 \%-100 \%$ & Tinggi \\
\hline $50 \%-74,99 \%$ & Sedang \\
\hline $25 \%-49,99 \%$ & Rendah \\
\hline $0 \%-24,99 \%$ & Sangat rendah \\
\hline
\end{tabular}

Berdasarkan hasil observasi aktivitas belajar di atas diketahui bahwa skor rata-rata aktivitas belajar siswa pada siklus I sebesear $43 \%$ belum memenuhi kriteria minimal rata-rata yaitu $75 \%$, memiliki kriteria aktivitas belajar yang masih rendah. Dan juga ketiga indikator masing-masing belum mencapai $75 \%$, untuk itu akan digunakan sebagai bahan refleksi dan diperbaiki pada siklus II. Pada akhir pembelajaran dilakukan tes yaitu dengan diberikannya tugas individu sebagai evaluasi siklus I terdiri dari 5 soal yang dibagikan melalui Google Classroom. Berikut hasil rekapitulasi dari nilai peserta didik pada tugas untuk evaluasi siklus I dengan materi "Tata Nama Senyawa Biner". Berikut adalah data hasil nilai tugas pada siklus I :

Tabel 3. Data Hasil Belajar Siswa Siklus I

\begin{tabular}{|c|c|}
\hline Hasil Penilaian & Hasil \\
\hline Nilai Rata-rata & 69 \\
\hline Nilai Tertinggi & 95 \\
\hline Nilai Terendah & 50 \\
\hline Jumlah Siswa yang Tuntas & 13 \\
\hline Jumlah Siswa yang Tidak Tuntas & 23 \\
\hline Prosentase Ketuntasan & $36 \%$ \\
\hline
\end{tabular}

Berdasarkan data pada tabel di atas dapat dijelaskan bahwa hasil belajar peserta didik kelas XTKJ-2 pada siklus I menunjukan nilai rata-rata 69 dari 36 siswa. Dengan prosentase ketuntasan sebesar $36 \%$ dimana sekitar 13 siswa yang memiliki nilai diatas KKM. Hasil belajar siswa dikatakan meningkat 
apabila prosentase ketuntasan sebesar 75\%, yaitu sekitar 27 siswa harus memiliki nilai diatas KKM atau "Tuntas". Pada siklus I prosesntase ketuntasan sebesar 36\% ,dimana 13 siswa dikatakan "Tuntas", sedangkan 23 siswa dikatakan "Belum Tuntas" yang berarti masih sangat rendah Hal ini diketahui dari hasil rata-rata bahwa dikatakan "Belum Tuntas" karena nilai rata-rata masih dibawah KKM yang ditentukan sekolah yaitu 70. Nilai tertinggi yaitu 95 dan nilai terendah adalah 50. Untuk itu perlu dilakukan siklus II untuk mengatasi masalah tersebut.

Pada tahap perencanaan pembelajaran siklus II, perencanaan dibuat berdasarkan kelemahan dan kendala yag ada pada siklus I sehingga masalah belum terselesaikan, dimana nilai rata-rata yang dihasilkan masih dibawah KKM dan prosentase ketuntasan masih rendah, untuk itu perlu dicari lagi pemecahannya. Tindakan perbaikan yang akan dilakukan sama dengan yang ada pada siklus I yaitu menggunakan model Siklus belajar 5E dengan media Power Point menggunakan aplikasi Google Classroom dan WhatsApp Group yang dilaksanakan melalui lima tahapan yaitu Tahap Pembangkitan Minat (Engigemant), Tahap Eksplorasi (Eksploration), Tahap Penjelasan (Explaination), Tahap Elaborasi (Elaboration), Tahap Evaluasi. Pada pembelajaran Kimia dengan materi "Tata Nama Senyawa Biner" dilakukan diskusi melalui WhatsApp Group. Pada siklus dilakukan diskusi dengan menampilkan contoh pengerjakan dan penjelasan melalui voice note. Hasil pengolahan aktivitas belajar siklus I secara rinci disajikan dalam tabel sebagai berikut:

Tabel 4. Skor Aktivitas Belajar Berdasarkan Observasi Siklus II

\begin{tabular}{|l|l|c|}
\hline No. & \multicolumn{1}{|c|}{ Indikator } & Skor \\
\hline 1. & Aktivitas Bertanya & $80 \%$ \\
\hline 2. & Aktivitas menjawab pertanyaan & $75 \%$ \\
\hline 3. & Aktivitas mengerjakan tugas & $85 \%$ \\
\hline \multicolumn{2}{r}{ Skor Rata-rata } & $\mathbf{8 0} \%$ \\
\hline
\end{tabular}

Menurut Arikunto (2009) pada Mandasari (2021) adalah pedoman kriteria ktivitas siswa pada pembelajaran sebagai berikut:

Tabel 5. Pedoman Kriteria Aktivitas Siswa

\begin{tabular}{|c|c|}
\hline Capaian & Kriteria \\
\hline $75 \%-100 \%$ & Tinggi \\
\hline $50 \%-74,99 \%$ & Sedang \\
\hline $25 \%-49,99 \%$ & Rendah \\
\hline $0 \%-24,99 \%$ & Sangat rendah \\
\hline
\end{tabular}

Berdasarkan hasil observasi aktivitas belajar siswa pada siklus II rata-rata nilai skor didapatkan $80 \%$ dan telah melebihi kriteria minimal yaitu sebesar 75\%, dan memiliki kriteria tinggi menurut pedoman kriteria aktivitas siswa. Sedangkan ketiga indikator aktivitas belajar sudah berada diatas kriteria minimal yaitu 75\%, sehingga dapat dikatakan bahwa aktivitas siswa meningkat.Setelah pembelajaran pada siklus II selesai, siswa diberikan tugas yang terdiri dari 5 soal yang dibagikan melalui GoogleClassroom. Berikut hasil rekapitulasi dari nilai siswa pada tugas untuk evaluasi siklus II dengan materi "Tata Nama Senyawa Biner":

Tabel 6. Data Hasil Belajar Siswa Siklus II

\begin{tabular}{|c|c|}
\hline Hasil Penilaian & Hasil \\
\hline Nilai Rata-rata & 84 \\
\hline Nilai Tertinggi & 100 \\
\hline Nilai Terendah & 65 \\
\hline Jumlah Siswa yang Tuntas & 30 \\
\hline Jumlah Siswa yang Tidak Tuntas & $\mathbf{8 3 \%}$ \\
\hline Presentase Ketuntasan & \\
\hline
\end{tabular}

Berdasarkan data pada tabel di atas dapat dijelaskan bahwa hasil belajar siswa kelas X-TKJ-2 pada siklus II menunjukan nilai rata-rata 84 dari 36 siswa. Dengan persentase ketuntasan sebesar $83 \%$ dimana terdapat sekitar 30 siswa yang memiliki nilai diatas KKM yang tentukan sekolah yaitu 70 yang 
berarti hasil belajar siswa sudah tinggi sehingga hasil belajar siswa dikatakan meningkat. Terdapat 30 siswa yang memiliki nilai diatas KKM 70 dikatakan "Tuntas", sedangkan Nilai tertinggi yaitu 100 dan nilai terendah adalah 65 .

Berdasarkan hasil pada siklus II terdapat adanya peningkatan aktivitas belajar siswa yang ditunjukan dengan peningkatan skor rata-rata aktivitas belajar siswa pada indikator yang ditetapkan dengan kriteria aktivitas belajar siswa tinggi. Refleksi perbaikan dari siklus I sampai siklus II yang berhubungan dengan kegiatan berdiskusi melalui WhatsApp Group mengakibatkan adanya peningkatan peran siswa dalam aktivitas bertanya, aktivitas menjawab pertanyaan dan aktivitas mengerjakan tugas. Pada penelitian ini menerapan model Siklus belajar 5E dengan materi yang dibuat menggunakan PowerPoint dan dibagikan menggunakan Google Classroom serta berdiskusi pada WhatsApp Group memiliki tujuan yaitu untuk mengetahui peningkatan aktivitas belajar dan hasil belajar siswa kelas XTKJ-2. Berdasarkan analisis penelitian diketahui bahwa terdapat peningkatan aktivitas belajar siswa kelas X-TKJ-2 SMK Negeri 1 Nganjuk, Hal ini terlihat dari adanya peningkatan yang mencerminkan aktivitas belajar yang dilakukan siswa selama proses pembelajaran daring berlangsung, kegiatan yang dilakukan siswa telah memenuhi kriteria yang ditetapkan dalam indikator-indikator tentang aktivitas belajar siswa yang menunjukkan peningkatan pada saat Pra siklus ke Siklus I, dan dari Siklus I ke Siklus II. Peningkatan aktivitas belajar siswa yang terjadi dalam kegiatan pembelajaran terlihat sebagai berikut :

Tabel 7. Perbandingan Skor Aktivitas Belajar Siswa

\begin{tabular}{|l|c|c|c|}
\hline \multirow{2}{*}{\multicolumn{1}{c|}{ Indikator }} & \multicolumn{3}{c|}{ Skor } \\
\cline { 2 - 4 } & Pra Siklus & Siklus I & Siklus II \\
\hline Aktivitas Bertanya & $30 \%$ & $40 \%$ & $80 \%$ \\
\hline Aktivitas menjawab pertanyaan & $30 \%$ & $40 \%$ & $75 \%$ \\
\hline Aktivitas mengerjakan tugas & $40 \%$ & $50 \%$ & $85 \%$ \\
\hline Skor Rata-rata & $\mathbf{3 3 \%}$ & $\mathbf{4 3 \%}$ & $\mathbf{8 0} \%$ \\
\hline
\end{tabular}

Berdasarkan data di atas dapat terlihat adanya peningkatan aktivitas belajar siswa kelas X-TKJ-2 dengan penerapan model pembelajaran Siklus Belajar 5E dengan menggunakan media PowerPoint dimana rata-rata Pra Siklus sebesar 33\%, meningkat 10\% pada Siklus I, dan pada Siklus II meningkat sebesar 37\%. Pada siklus II skor rata-rata aktivitas belajar siswa sebesar $80 \%$ dimana telah melebihi kriteria minimal yaitu sebesar $75 \%$. Berikut berdasarkan grafik perbandingan aktivitas belajar siswa kelas X-TKJ-2 :

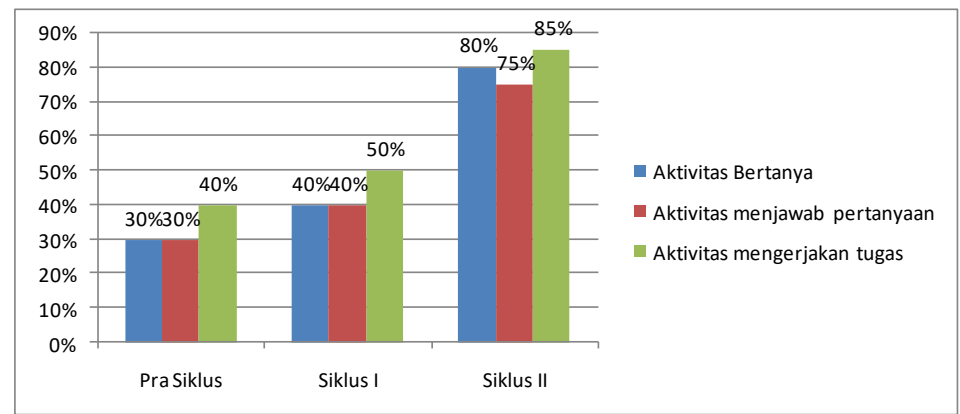

Gambar 2. Diagram Aktivitas Belajar Siswa

Berdasarkan hasil penelitian yang sudah dilakukan, menunjukan bahwa penerapan model pembelajaran Siklus Belajar 5E dengan media PowerPoint dapat meningkatkan hasil belajar siswa pada pembelajaran kimia dengan materi "Tata Nama Senyawa Biner". Hal tersebut dapat dilihat pada nilai tugas mandiri yang dilakukan pada Pra Siklus, Siklus I, dan Siklus II. Berikut tabel perbandingan hasil nilai tugas mandiri siswa :

Tabel 8. Capaian Hasil Belajar Siswa

\begin{tabular}{|c|c|c|c|}
\hline Capaian & Pra Siklus & Siklus I & Siklus II \\
\hline Rata-rata & 66 & 69 & 84 \\
\hline Nilai Tertinggi & 90 & 95 & 100 \\
\hline Nilai Terendah & 45 & 50 & 65 \\
\hline
\end{tabular}




\begin{tabular}{|c|c|c|c|}
\hline Jumlah Nilai $>70$ & 10 & 13 & 30 \\
\hline Prosentase ketuntasan & $\mathbf{2 8 \%}$ & $\mathbf{3 6 \%}$ & $\mathbf{8 3 \%}$ \\
\hline
\end{tabular}

Berdasarkan data di atas terlihat adanya peningkatan hasil belajar siswa kelas X-TKJ-2 dengan penerapan model pembelajaran Siklus Belajar 5E menggunakan PowerPoint. Pada Pra Sikus prosentase ketuntasan sebesar 28\%, sedangkan pada Siklus I sebesar 8\%, dan pada Siklus II meningkat $47 \%$. Prosentase ketuntasan pada siklus II sebesar $83 \%$, dimana sudah mencapai kriteria keberhasilan yang ditentukan yaitu $75 \%$. Berikut data yang dapat dilihat berdasarkan grafik :

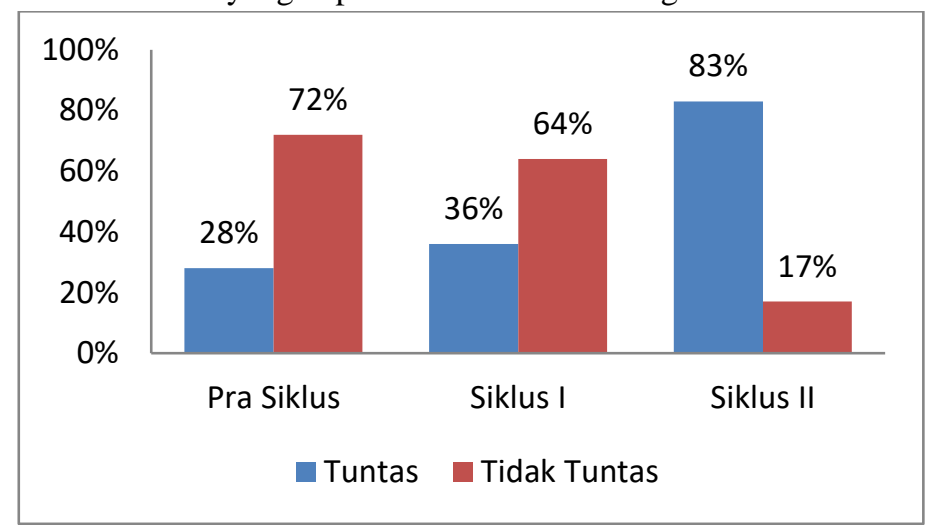

Gambar 3. Diagram Persentase Hasil Belajar Siswa

Perolehan persentase ketuntasan hasil belajar di Pra Siklus, dan Siklus I belum mencapai kriteria keberhasilan yang telah direncanakan, yaitu 28\% pada Pra Siklus, sedangkan Siklus I sebesar 36\% dari kriteria keberhasilan hasil belajar seharusnya $75 \%$. Meskipun demikian hasil persentase terebut mengalami peningkatan mulai dari Pra Siklus ke Siklus I. Siklus II diperoleh hasil 83\% sehingga telah mencapai kriteria minimal sebesar $75 \%$. Berdasarkan hasil belajar peserta didik sebelum diterapkannya pembelajaran Siklus Belajar 5E dengan media PowerPoint menggunakan Google Classroom dan WhatsApp Group pada Siklus I dan Siklus II mengalami peningkatan. Selain itu keberhasilan penggunaan model Siklus Belajar 5E menggunakan media power point dibuktikan juga melalui diagram rata-rata nilai tugas siswa kelas X-TKJ-2 mengalami peningkatan sebagai berikut:

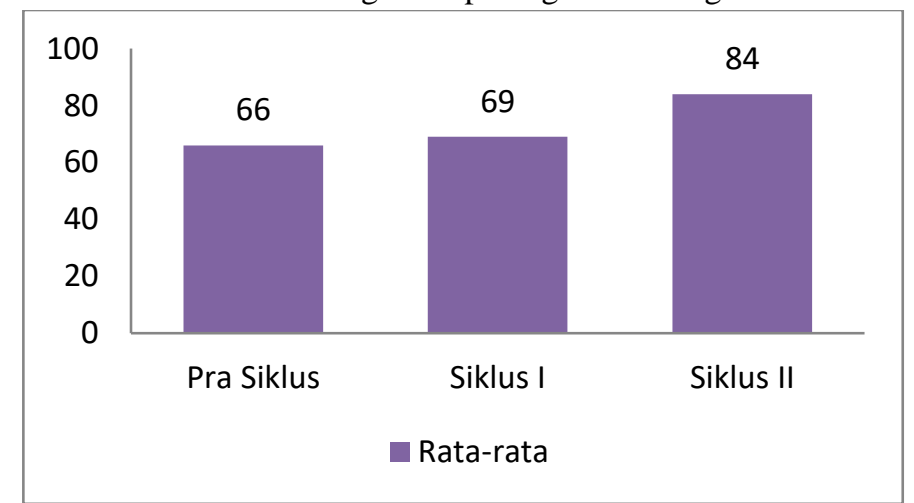

Gambar 4. Diagram Rata-rata Hasil belajar Peserta didik

Berdasarkan diagram diatas diperoleh nilai rata-rata dari setiap Siklus mengalami peningkatan, dari Pra Siklus diperoleh rata-rata sebesar 66, pada Siklus I diperoleh rata-rata 69, sedangkan di Siklus II diperoleh rata-rata 84 . Peningkatan tersebut disebabkan oleh beberapa faktor seperti proses adaptasi, bimbingan diskusi, pemahaman siswa, caraguru menjelaskan, media yang digunakan, fitur yang digunakan pada saat diskusi melalui WhatsApp Group. Pada siklus I, siswa secara keseluruhan belum bisa beradaptasi dengan model pembelajaran dengan Siklus Belajar 5E dengan media PowerPoint dan penggunaan aplikasi Google Classroom untuk penugasan serta diskusi pada WhatsApp Group sehingga masih belum memahami secara kseseluruhan. Pada siklus II, peserta didik sudah beradaptasi dengan model pembelajaran siklus belajar 5E dengan media PowerPoint serta penggunaan WhatsApp group sebagai tempatdiskusi serta penugasan pada Google Classroom sehingga siswa lebih aktif dalam diskusi dan memiliki hasil belajar yang baik dalam mengerjakan tugas. 


\section{KESIMPULAN}

Berdasarkan hasil penelitian yang telah dilakukan dapat disimpulkan bahwa penerapan model Siklus Belajar 5E dengan media PowerPoint serta penggunaan WhatsApp Group untuk diskusi dan Google Classroom untuk penugasan dapat meningkatkan aktivitas belajar siswa kelas X-TKJ-2 SMK Negeri 1 Nganjuk. Dengan menggunakan observasi terhadap hasil aktivitas belajar siswa pada pra siklus diperoleh skor 33\%, siklus I naik 10\% diperoleh skor 43\%, pada siklus II naik 37\% diperoleh skor 80\%. Penerapan model Siklus Belajar 5E dengan media PowerPoint serta penggunaan WhatsApp Group untuk diskusi dan Google Classroom untuk penugasan dapat meningkatkan hasil belajar kelas X-TKJ-2. Hal tersebut dapat dilihat dari hasil aktivitas belajar siswa pada pra siklus diperoleh skor 33\%, siklus I naik 10\% diperoleh skor 43\%, pada Siklus II naik 37\% diperoleh skor $80 \%$, telah melebihi kriteria minimal yaitu sebesar $75 \%$, dan memiliki kriteria tinggi sesuai pedoman kriteria aktivitas siswa. Untuk hasil belajar siswa pada Pra Siklus prosentase ketuntasan hasil belajar siswa adalah 28\%, kemudian pada Siklus I sebesar 36\%, Siklus II meningkat hingga 83\% siswa atau sekitar 30 siswa yang memiliki nilai "Tuntas" atau diatas KKyang telah ditentukan sekolah yaitu 70 .

\section{UCAPAN TERIMAKASIH}

Terimakasih saya ucapkan kepada Ibu Yulia Dewi Puspitasari, M.Pd selaku Dosen Pengampu Mata Kuliah Seminar Pendidikan IPA yang telah memberikan kami tugas untuk melakukan penelitian di sekolah SMK Negeri 1 Nganjuk serta siswa Kelas X-TKJ-2 yang telah bekerja sama dan membantu dalam pelaksanaan penilitan ini serta semua pihak yang tidak bisa saya sebutkan satu-persatu.

\section{REFERENCES}

[1] Abdullah, W. (2018). Model Blended Learning Dalam Meningkatkan Efektifitas Pembelajaran. Fikrotuna: Jurnal Pendidikan Dan Manajemen , 7, 857.

[2] Dakhi, A. S. (2020). Peningkatan Hasil Belajar Siswa. Jurnal Education And Development , 8.

[3] Inayah, N. (2019). Keefektifan Metode Blended Learning Berbasis Multimedia Untuk Analisis Pemahaman Konsep Dan Pengembangan Karakter Peserta Didik Pada Materi Senyawa Hidrokarbon. Tesis , Pp. 6-7.

[4] Harjanto, AS \& Sumarni, S. 2019. Teachers' Experiences On The Use Of Google Classroom. Proceedings 3rd English Language And Literature InternationalConference (Ellic) Vol. 3 EISSN: 2579-7263, ISSN: 2579-7549.

[5] Kanza. (2020). Analisis Keaktifan Belajar Siswa Menggunakan Model Project Based Learning Dengan Pendekatan Stem Pada Pembelajaran Fisika . Jurnal Pembelajaran Fisika .

[6] Kristina, M. (2020). Model Pelaksanaan Pembelajaran Daring Pada Masa Pandemi Covid 19 Di Provinsi Lampung. Jurnal Idaarah, , IV. 2. 201-209

[7] Limbong, C. (2019). Meningkatkan Motivasi Belajar Dan Penguasaan Konsep Dengan Model Pembelajaran Siklus Belajar Tipe 5E Di Kelas X IPA 3 SMAN 9 Kota Bengkulu. Jurnal Kumparan Fisika , 34.

[8] Mandasari, A.N. 2021. Penerapan Model Pembelajaran Berbasis Masalah Berbantuan Media Power Point untuk Meningkatkan Aktivitas dan Hasil Belajar Siswa SDN Pandean Lamper 02 Semarang. Jurnal Paedagogy: Jurnal Penelitian dan Pengembangan Pendidikan. Vol. 8 No. 3. pp. 328-337

[9] Maharani, N \& Kartini, KS. 2019. Penggunaan Google Classroom Sebagai Pengembangan Kelas Virtual Dalam Keterampilan Pemecahan Masalah Topik Kinematika Pada Mahasiswa Jurusan Sistem Computer. PENDIPA Journal Of Science Education, Vol 3(3), Pp: 167-173

[10] Muthoharoh, M. (2019). Media Powerpoint Dalam Pembelajaran. Tasyri’, Vol. $26,23$. 
[11] Nugroho, P. A. (2020). Analisis Penggunaan Media Pembelajaran Google Classroom Terhadap Keaktifan Dan Hasil Belajar Mahasiswa Pendidikan IPA Selama Pandemi Covid-19. Prosiding Seminar Nasional Online (Webinas), (Pp. 142-153).

[12] Sukmawati \& Nensia. The Role of Google Classroom in ELT. International Journal for Educational and Vocational Studies, Vol. 1(2), pp: 142-145.

[13] Samsu. (2017). METODE PENELITIAN:(Teori Dan Aplikasi Penelitian Kualitatif,Kuantitatif, Mixed Methods, Serta Research \& Development). 